\title{
Effectiveness of an educational game-based intervention for enhancing nutritional knowledge of elementary school students
}

\author{
Lucas Florêncio de Brito, UNIVASF, Brasil, lucasdibex@gmail.com, \\ http:0000-0002-2409-430X \\ Ricardo Argenton Ramos, UNIVASF, Brasil, ricargentonramos@gmail.com, \\ http://orcid.org/0000-0002-9688-719X \\ Jaelson Freire Brelaz de Castro, UFPE, Brasil, jbc@cin.ufpe.br, \\ http://orcid.org/0000-0002-4635-7297 \\ João Araújo, Universidade Nova de Lisboa, Portugal, joao.araujo@fct.unl.pt, \\ http://orcid.org/0000-0001-5914-1631 \\ Rodrigo Pereira Ramos, UNIVASF, Brasil, rodrigo.ramos@univasf.edu.br, \\ http://orcid.org/0000-0002-9243-3887
}

\begin{abstract}
Obesity can generate short and long term effects on health. Nutritional knowledge is important to increase the potential of acquiring healthy eating habits and prevent obesity. In this study, it was investigated an educational game-based intervention with the Nutrikids digital game to improve nutritional knowledge. One hundred and sixty-four Brazilians fifth graders were divided into the following four groups: one that played the Nutrikids game; the lecture-game group, which received traditional classes and played Nutrikids; the lecture group, which received traditional classes only; and the control group, with no intervention. The results suggest that nutritional knowledge in students can be improved more effectively through game-based learning than traditional classes.
\end{abstract}

Keywords: Serious Game. Game-based Learning. Nutrition Education.

\section{Efetividade de um intervenção baseada em jogos para aumentar o conhecimento educacional de estudantes do ensino fundamental}

Resumo: A obesidade pode gerar efeitos na saúde tanto a curto quanto a longo prazo, o conhecimento nutricional é importante para aumentar o potencial de adquirir hábitos alimentares saudáveis e prevenir a obesidade. Neste estudo, foi investigado uma aprendizagem baseada em jogos com o jogo digital Nutrikids para melhorar o conhecimento nutricional. Cento e sessenta e quatro estudantes brasileiros do quinto ano foram divididos nos seguintes grupos: um que jogou apenas o Nutrikids; o grupo aula-jogo que recebeu aulas tradicionais e jogou o Nutrikids; o grupo aula que recebeu apenas aulas tradicionais; e o grupo jogo sem intervenção. Os resultados sugerem que o conhecimento nutricional em estudantes pode ser melhorado mais eficazmente através do uso de aprendizagem baseada em jogos do que aulas tradicionais.

Palavras-chave: Jogos Sérios. Aprendizagem Baseada em Jogos. Educação Nutricional.

\section{Introduction}

Obesity is considered a worldwide epidemic in both developed and developing countries, and it has increased in the last few years. In 2016, nearly $11.75 \%$ of the adult male population and $15.70 \%$ of the adult female population were obese; as for children and teenagers, this index reached 5.6\% for girls and 7.8\% for boys (Arbaca-Gómez et al., 2017). In Brazil, in 2017, 18.9\% of adults were obese (Brazil, 2018), and the forecast is that, in 2025 , the country will occupy fourth place in the ranking of countries 
with the largest number of children and teenagers with weight excess in the world (Lobstein; Jackson-Leach, 2016).

Obesity has a complex and multifactorial origin, and it can generate short and long term effects on health, acting as a risk factor for cardiovascular diseases; type 2 diabetes; liver, gastrointestinal, metabolic, and bone problems; stroke; cancer; sleep apnea; Alzheimer's disease; and neurodegenerative diseases (Hamer and Batty, 2019).

Prevention relies on decreasing high-calorie foods, increasing physical activity, and promoting nutritional knowledge regarding healthy eating habits (Onis, 2015); it is important to promote this knowledge in the school environment since childhood (Nishtar, Gluckman and Armstrong, 2016). For children and teenagers, this knowledge has been revealed to be deficient, and many of them prefer to learn this subject through digital games (Holzmann et al., 2019). In this perspective, educational games figure as a promising strategy for health development in children, with the capacity to stimulate healthy habits related to nutritional knowledge (Baranowski et al., 2019; Machado et al., 2020).

Educational games are those that contribute to the teaching and learning process (Prensky, 2012). The use of educational games has been demonstrated to be positive by students who consider them attractive and pleasant (Sera and Wheeler, 2017) and, therefore, able to motivate the learning process (Reis, Vasconcellos and Barros, 2011), aid in knowledge development based on learning experiences acquired through games (Abdul Jabbar and Felicia, 2015), produce greater knowledge acquisition (Connolly et al., 2012), and it can impact cognitive, emotional, and social areas (Savi and Ulbricht, 2008).

Teachers who employ digital game-based learning in the classroom notice greater engagement of students, making them more enthusiastic and, consequently, producing greater cognitive learning (Huizenga et al., 2017). When comparing educational games with traditional methodologies, such as lecture classes and reading, educational games usually obtain greater learning gains and exposure to cognitive abilities, in addition to promoting greater knowledge retention (Wouters et al., 2013; Vogel et al., 2006).

In this study, we aimed to widen the evidence on the effectiveness of game-based learning when analyzing the effect of applying the Nutrikids game for teaching nutritional knowledge, in Brazilian students between 9 and 12 years old, by comparing learning through the game with traditional expository lectures, a combination of traditional lectures and the game, and a group with no intervention. In this manner, the research question that guided this study was the following:

RQ - What is the impact of playing the Nutrikids game on nutritional knowledge when compared to expository lectures and to a control group immediately after the intervention and at one month of follow-up?

To evaluate this impact, the following four groups settings were defined: the game group (GG), which received the intervention with Nutrikids; the lecture group (LG), which received traditional lecture classes only; the lecture-game group (LGG), which received half of the intervention with traditional classes and the other half with Nutrikids; and the control group (CG), with no intervention. A pre-test on nutritional knowledge, a first post-test immediately following the last intervention, and a second post-test one month after the first post-test were administered to measure knowledge gain and retention.

Therefore, the following hypotheses tested in this study were: 
- Hypothesis 1: The knowledge improvement obtained after the intervention was the same for boys and girls;

- Hypothesis 2: The GG obtained significant learning improvement on the first post-test;

- Hypothesis 3: The LGG obtained significant learning improvement on the first post-test;

- Hypothesis 4: The GG presented greater learning improvement when compared to the CG, the LG, and the LGG on the first post-test;

- Hypothesis 5: The GG presented greater knowledge retention when compared to the CG, the LG, and LGG on the second post-test.

\section{Method}

For this pilot study, a quasi-experimental group randomization design was used to assess the effectiveness of game-based learning for improving nutritional knowledge in Brazilian students, between March and May 2019. Young students were recruited in a convenience sample of four Brazilian public schools from low-income areas where lessons are not typically taught on computers; the participants were between the ages of 9 and 12 years, and they were attending the fifth year of elementary school.

\subsection{Participants}

One hundred and ninety-three students from the four included schools were selected for eligibility; a total of 8 were excluded before the beginning of the study, 5 who were over 12 years old and 3 who had pathologies that limited cognitive development. From these, 185 remained, and they were cluster-randomized and allocated according to their corresponding school group (Fig. 1).

The sample was divided into the following four groups, with each school corresponding to a single group assigned by draw: the $\mathrm{CG}, 35$ students with no intervention; the LG, 63 students, who received traditional lecture classes on the same topics as the game; the GG, 59 students, for whom the entire intervention was performed with the Nutrikids game; and the LGG, 28 students, for whom half of the intervention consisted of traditional lecture classes and the other half of the Nutrikids game. After the interventions, loss to the follow-up occurred, and there remained 34 participants in the CG, 49 in the LG, 54 in the GG, and 27 in the LGG for analysis. There was no withdrawal; the losses (students who missed one of the tests) corresponded to $11.35 \%$, and the final sample comprised 164 students. 


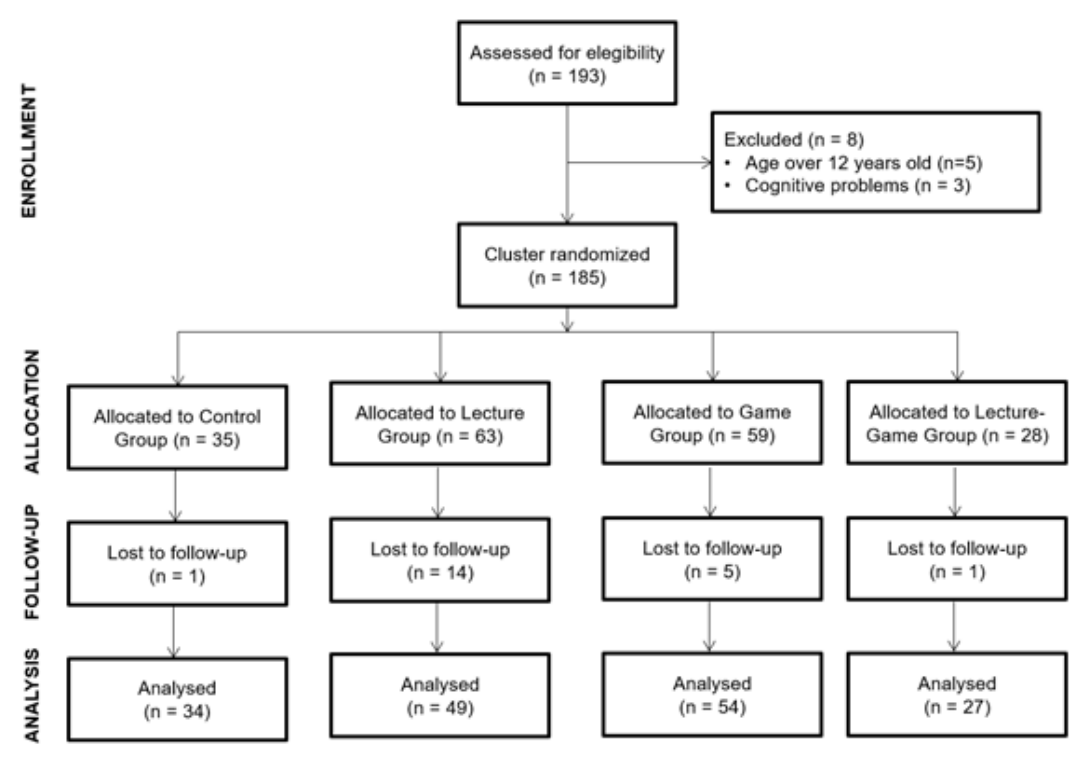

Fig 1. Consort statement for participant recruitment

\subsection{Measures}

The children's anthropometric measurements (height and weight) were obtained to calculate body mass index (BMI), in order to verify nutritional status. To verify nutritional knowledge, the Nutritional Knowledge Questionnaire (NKQ) developed by Parmenter and Wardle (1999) and adapted to Portuguese by Souza (2009) was employed. The questionnaire is divided into four sections. The first is about the dietary recommendations by specialists; the second addresses food groups; the third covers the healthiest food choices, and the fourth addresses the relation of diseases with bad eating habits (Souza, 2009). At the end, based on the correct responses, a grade from 0 to 59 is generated. Nutritional knowledge was measured based on the NKQ in three different moments: pre-test (before the intervention), post-test 1 (one week after the intervention), and post-test 2 (one month after pre-test 1 ).

\subsection{Procedures}

During the first week of study in the schools, the project was presented to the children, and parental consent was obtained for participation. Once approval was obtained, each school was randomly assigned to a group, and the students who had provided consent to participate in the study took the pre-test with the Nutritional Knowledge Questionnaire (NKQ), and their baseline characteristics were measured by the researchers.

The students in the GG played Nutrikids once a week for a month during their science classes. There were four half-hour sessions. Each student played the game on a computer, tablet, or smartphone with the supervision of researchers, and they had to complete all the categories of the game. The students in the LG received traditional lecture classes from the same researchers, on the same subjects addressed in the game, during the same intervention period. The students in the LGG received half of the intervention ( 2 sessions) with traditional expository lectures and the other half with the Nutrikids game. The CG underwent no intervention. Both the educational game and the expository lectures were based on the first and second editions of the Food Guide for the Brazilian Population (Brazil, 2008; Brazil, 2014). The NKQ was re-applied one 
week after the end of the interventions in all groups, with these scores corresponding to post-test 1 , and one month after the last test, providing the post-test 2 scores.

\subsection{Data Analysis}

All data were analyzed using the software Statistical Package for the Social Sciences (SPSS), version 25.0, with a significance level (p-value) set at 5\%. Descriptive measures (mean and standard deviation) were used to represent the study participants. For variables that did not present normality, their non-parametric correspondents were used. To verify the difference between quantitative variables in groups, a one-way analysis of variance (ANOVA) was performed, along with a chi-squared test for qualitative variables.

To verify if the different interventions and the sex of the students influenced the scores obtained in the tests, two-way analysis of variance was applied for the type of intervention (four categories: game, lecture, lecture-game, and control) and sex (two categories: female and male), totaling a $4 \times 2$ factorial. The factors that significantly influenced students' scores were later investigated using Tukey's test.

Variation in the scores of students in each group throughout time was investigated using quadratic polynomial regression models. The beta terms of the generated models were used to compare the strength of the effect of each type of intervention, also performing analyses of variance with repeated measures, followed by multiple comparisons to verify whether the mean student scores in each group differed significantly between tests.

\subsection{The Nutrikids game}

Nutrikids is a serious digital quiz game in Brazilian Portuguese developed using the Unity 3D game engine, version 2018.3.3, to aid in the learning of nutritional knowledge for children and teenagers. Its target audience is children from 8 years old, and it can be used on computers, tablets, and smartphones. The game addresses the subject of the types of food processing (processed, ultra-processed, minimally processed, or unprocessed), high-sodium foods, sugars, and saturated fats, food groups, fundamental foods for healthy eating, and diseases related to bad eating habits. The game can be found at https://bityli.com/P0Gem.

For the development of the game, the ENgGAGED (Educational Game Development) process was used, which is a methodology consisting of five phases (analysis, design, development of the educational game, execution, and evaluation) used to develop educational games that aim to unite the processes of game design and instructional design in a balanced manner (Battistella and von Wangenheim, 2016).

When starting the game, the player is taken to a screen where it is possible to choose one of the following categories, in any order: carbohydrates, healthy eating habits, calcium, fruits, vegetables and legumes, fats, proteins, and processed food (Fig. 2: top-left). After choosing the category, the player advances to the screen with the information about the selected theme (Fig. 2: top-right), and the player can spend any amount of time reading the respective information for each topic; when finished reading, the player is taken to the questions screen (Fig. 2: bottom-left), where there are multiple-choice questions with text, multiple-choice questions with images, or true or false questions. Players have 25 seconds for each question; they begin the game with three hearts, and they lose one for every wrong answer or when time runs out (Fig. 2: bottom-right). 
The game responds whether an answer was right or wrong; when it is wrong, the right answer is highlighted. In the end, the player receives the number of stars for that category, corresponding to the number of hearts remaining, and it is possible to answer the questions for each category as many times as wanted.
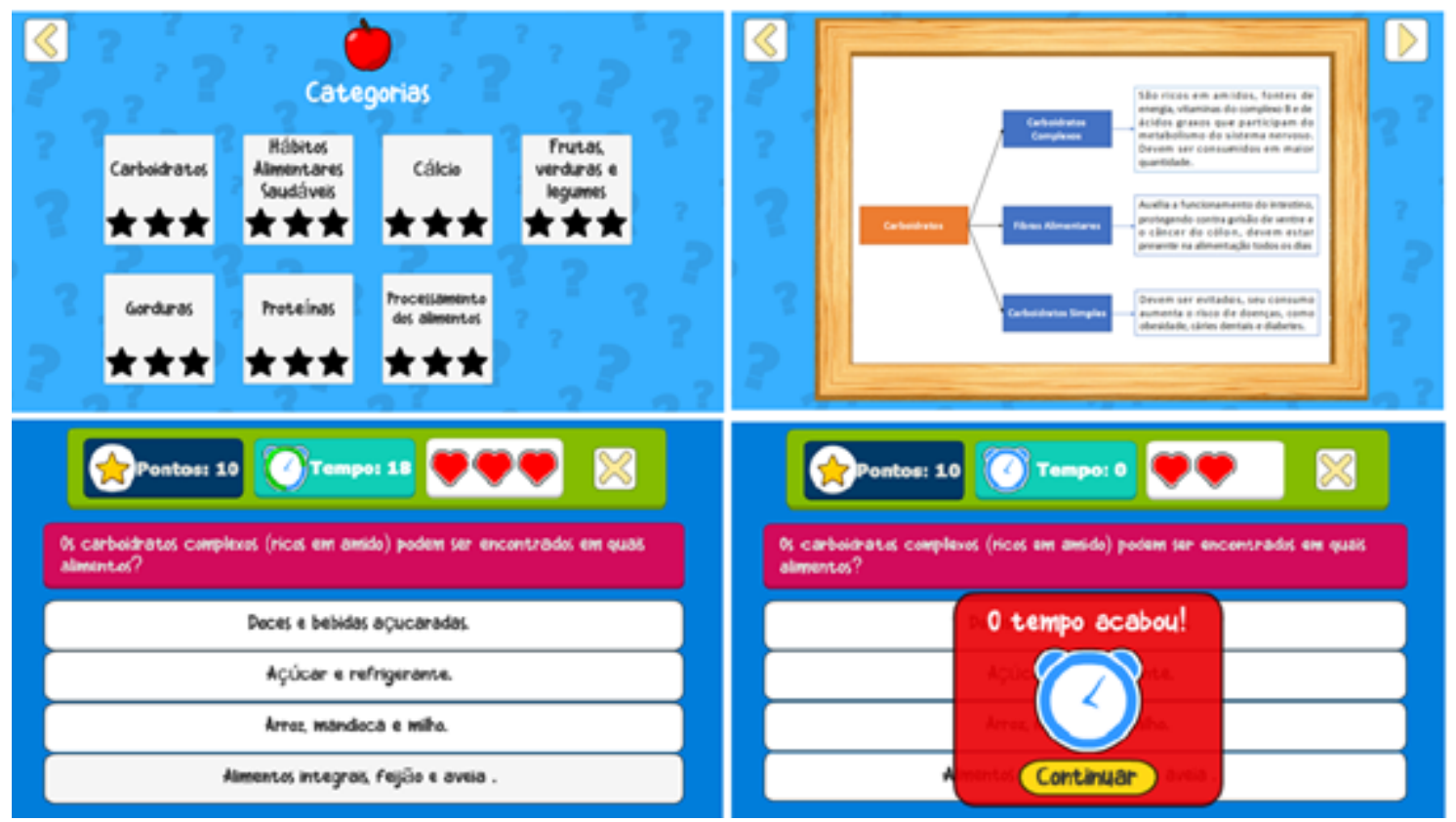

Fig. 2. Top-left: Screen for the choice of question categories. Top-right: Screen with information about the selected category. Bottom-left: Example of a screen with multiple-choice questions. Bottom-right: Screen indicating that time has run out.

\section{Results and Discussion}

\subsection{Sample Characterization}

Sample characterization is presented in Table 1. The variables BMI, and age were non-parametric; therefore, the Kruskal-Wallis test was used to verify the homogeneity of groups. There were no differences between the means of the groups for BMI $[\chi 2(3)=1.857 ; \mathrm{p}=0.603]$, whereas there was a significant difference between the age means in each group. Tukey's post hoc test showed that these differences occurred between the LG $(10.16 \pm 0.51$ years $)$ and $\mathrm{CG}(9.85 \pm 0.43$ years $)$, as well as between the CG (9.85 \pm 0.43 years $)$ and GG (10.24 \pm 0.43 years $)$.

The variable of $\mathrm{z}$ score and pre-test scores were shown to be parametric and homogeneous; therefore, one-way ANOVA was used to verify whether there were differences between groups. As a result, no difference between group means was found for $\mathrm{z}$ score $[\mathrm{F}(3,160)=1.154 ; \mathrm{p}=0.329]$. Regarding the percentage of boys and girls in the group, since it is a qualitative variable, the chi-squared test was employed, resulting in no difference $[\chi 2(3)=0.898 ; \mathrm{p}=0.826]$. Therefore, the groups were shown to be similar in their characteristics.

Table 1 - Baseline comparisons 


\begin{tabular}{lccccccc}
\hline Variable & $\begin{array}{c}\mathrm{LG}(\mathrm{n}= \\
63)\end{array}$ & $\begin{array}{c}\mathrm{GG}(\mathrm{n}= \\
59)\end{array}$ & $\begin{array}{c}\mathrm{LGG}(\mathrm{n} \\
=28)\end{array}$ & $\begin{array}{c}\mathrm{CG}(\mathrm{n}= \\
35)\end{array}$ & $\begin{array}{c}\text { Total }(\mathrm{n} \\
=185)\end{array}$ & $\mathrm{F} / \mathrm{X}^{2}$ & $\mathrm{p}$ value \\
& $\mathrm{M} \pm \mathrm{SD}$ & $\mathrm{M} \pm \mathrm{SD}$ & $\mathrm{M} \pm \mathrm{SD}$ & $\mathrm{M} \pm \mathrm{SD}$ & $\mathrm{M} \pm \mathrm{SD}$ & & \\
\hline Age (years) & $10.16 \pm$ & $10.24 \pm$ & $10.15 \pm$ & $9.85 \pm$ & $10.12 \pm$ & 15.412 & 0.01 \\
& 0.51 & 0.43 & 0.45 & 0.43 & 0.48 & & \\
$\mathrm{BMI}$ & $17.85 \pm$ & $17.99 \pm$ & $18.97 \pm$ & $19.00 \pm$ & $18.32 \pm$ & 1.857 & 0.603 \\
$\left(\mathrm{~kg} / \mathrm{m}^{2}\right)$ & 3.83 & 3.04 & 3.91 & 4.49 & 3.75 & & \\
Z score & $0.03 \pm$ & $0.25 \pm$ & $0.57 \pm$ & $0.53 \pm$ & $0.29 \pm$ & 1.154 & 0.329 \\
& 1.70 & 1.24 & 1.34 & 1.51 & 1.46 & & \\
$\begin{array}{l}\text { Male Sex } \\
(\%)\end{array}$ & 48.98 & 51.85 & 55.56 & 44.12 & 50 & & \\
Female Sex & 51.02 & 48.15 & 44.44 & 55.88 & 50 & 0.898 & 0.826 \\
$(\%)$ & & & & & & & \\
\hline
\end{tabular}

Note: $\mathrm{LG}=$ lecture group; $\mathrm{GG}=$ game group; $\mathrm{LGG}=$ lecture-game group; $\mathrm{CG}=$ control group; $\mathrm{M}=$ mean; $\mathrm{SD}=$ standard deviation.

\subsection{Nutritional Knowledge}

The descriptive statistics of the nutritional knowledge results are shown in https://drive.google.com/file/d/1-OAQBwShLIR7pdZsZVm06On5uwTQcCnW/view?u $\mathrm{sp}=$ sharing. One-way mixed ANOVA showed that there was no effect of group $[F(3,160)=1.459 ; p=0.228]$, although there was an effect of time $[F(2,320)=38.537$; $\mathrm{p}<0.001]$ and the interaction of time with group $[\mathrm{F}(6,320)=13.368 ; \mathrm{p}<0.001]$. Tukey's post hoc test showed that, for both the LGG and GG, the highest scores were obtained on post-test 1 , and the lowest were on the pre-test. In the CG and the LC, the scores did not alter significantly between tests.

The factorial analyses of variance of the pre-test scores demonstrated that there was no significant difference between groups $[\mathrm{F}(3,156)=1.060 ; \mathrm{p}=0.368]$, sex [F $(1,156)=0.068 ; \mathrm{p}=0.795]$, and in the interaction of group with $\operatorname{sex}[\mathrm{F}(3,156)=0.172$; $\mathrm{p}=0.915]$. This result confirms that all volunteers presented similar nutritional knowledge before the interventions, satisfying one of the necessary conditions for the experiment (Fig. 3: top-left). The types of interventions influenced students' acquisition and retention of knowledge in different ways. In post-test 1 scores, no significant differences were found between sexes $[\mathrm{F}(1,156)=0.542 ; \mathrm{p}=0.463]$ or in the interaction between sex and group $[\mathrm{F}(3,156)=1.796 ; \mathrm{p}=0.150]$ (supporting Hypothesis 1), whereas a significant difference was found between groups $[\mathrm{F}(3,156)=8.120 ; \mathrm{p}<$ 0.001]. Tukey's post hoc test revealed that the GG obtained higher scores when compared to the LG and CG, although no difference was found when compared to the LGG (Fig. 3: top-right graph).

The scores of post-test 2 did not present significant differences between sexes [F $(1,156)=0.011 ; \mathrm{p}=0.917]$ and in the interaction between sex and group $[\mathrm{F}(3,156)=$ $0.439 ; \mathrm{p}=0.725]$. In parallel, a significant difference was found between groups [F $(3,156)=3.199 ; p=0.025]$. Tukey's post hoc test showed that the GG obtained a significantly higher score than the CG (Fig. 3: bottom chart). 


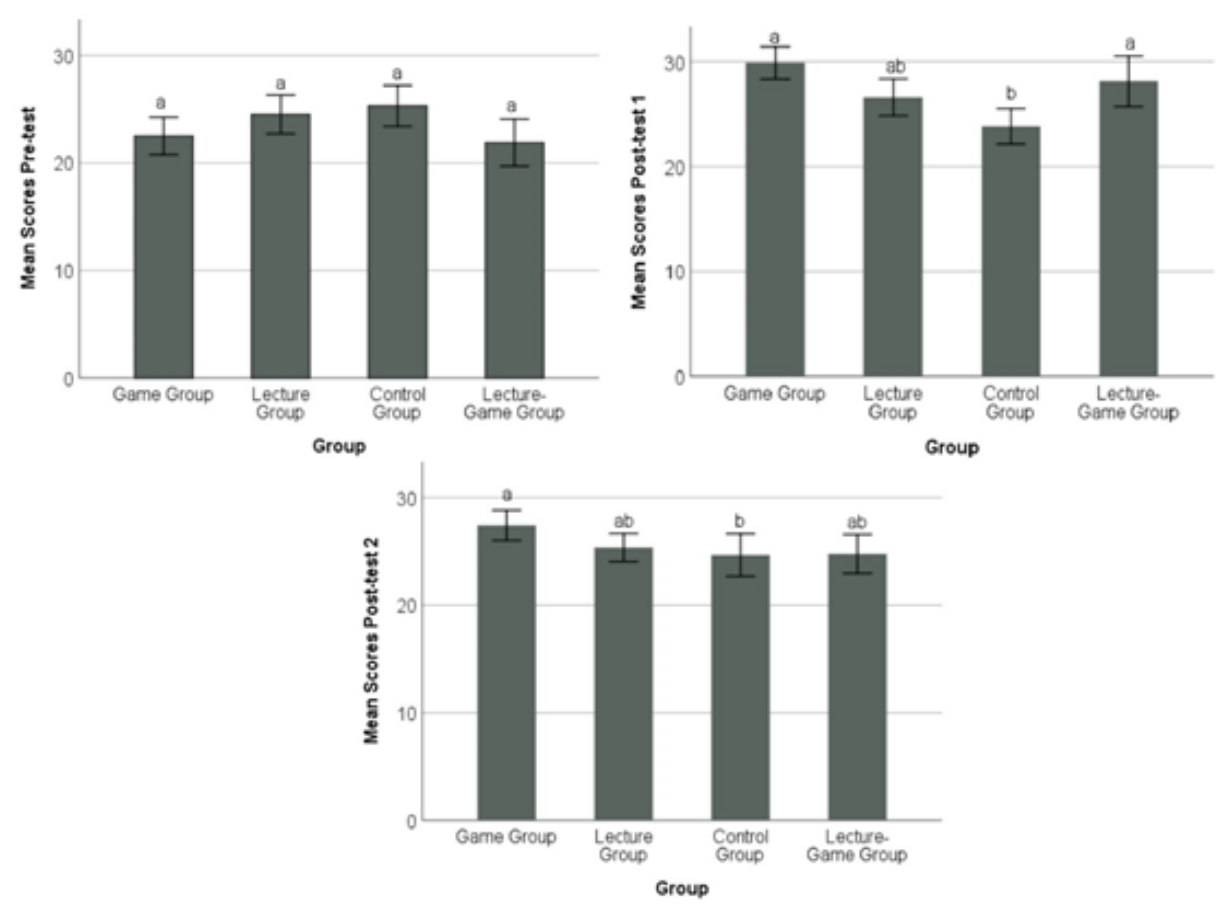

Fig. 3. Comparison of student group scores on the pre-test (top-left), post-test 1 (top-right), and post-test 2 (bottom) when receiving four types of intervention. The letters compare the group means on each test, according to Tukey's test. Different letters (in the horizontal) represent significant differences at a 95\% confidence level. Error bars equal $95 \%$ confidence interval.

Quadratic polynomial regression analyses demonstrated that both the game $[\mathrm{F}(2,159)=23.026 ; \mathrm{p}<0.001 ; \mathrm{R} 2=0.225]$ and the lecture-game interventions $[\mathrm{F}(2,78)$ $=8.975 ; \mathrm{p}<0.001 ; \mathrm{R} 2=0.187]$ raised students' scores regarding nutritional knowledge between the pre-test and post-test 1, supporting Hypotheses 2 and 3. The game-only intervention obtained the greatest effect on the scores $(\beta=12.31)$, followed by the lecture-game intervention $(\beta=11.07)$, supporting Hypothesis 4 only partially, since both the GG and the LGG ranked better than the LG and the CG. In both cases, there was a significant drop in scores between post-test 1 and post-test 2, demonstrating a loss in knowledge retention. Even so, students who received only the game obtained significantly higher scores than the $\mathrm{CG}$ on post-test 2 , and they presented greater knowledge retention, supporting Hypothesis 5. Both students who received only lectures and those in the $\mathrm{CG}$ did not present a significant score variation throughout time $(\beta=3.73$ and 2.57 , respectively).

Therefore, the highest scores were obtained by the students who received the intervention with games only, presenting means of $29.89 \pm 5.70$ and $27.43 \pm 5.16$ in post-tests 1 and 2, respectively. The lecture-game intervention resulted in the second-highest mean on post-test $1(28.15 \pm 6.09)$, although it did not differ from the CG in post-test $2(24.78 \pm 4.58)$. The scores of students who received only the lecture intervention did not differ significantly from the CG on any of the tests.

Based on these results, the answer to the guiding question is that the groups that received the intervention with the Nutrikids game (GG and LGG) obtained greater learning improvement on nutritional knowledge between the pre-test and post-test 1 when compared to the lecture only group and the group with no intervention. Regarding 
knowledge retention, only the GG was able to obtain higher scores on post-test 2, differently from the remaining groups

The five hypotheses are discussed based on the result findings and literature review:

Hypothesis 1: This hypothesis is confirmed, since there was no statistical difference between the scores of boys and girls, on all tests. The sex difference is an important issue to analyze, given that boys usually spend more time playing games than girls (Borgonovi, 2016), and this can influence knowledge acquisition.

Hypothesis 2: This hypothesis is also confirmed; in the GG, nutritional knowledge scores increased between the pre-test and post-test 1 . The results suggest that the game was more efficient in providing information than other methods because the students were more engaged in obtaining the best scores and the highest number of stars and in achieving what was needed to acquire the knowledge presented in the game.

This result follows past findings that showed that game-based learning in school children increased engagement and motivation and, consequently, improved learning (Byun and Joung, 2018; Huizenga et al., 2017).

Hypothesis 3: This hypothesis is also confirmed. This result is interesting because it shows that both the use of the game and the game along with traditional classes promoted an increase in the pre-test and post-test 1 scores, suggesting that it is possible to align traditional methods with new educational tools, such as game-based learning since they are not exclusive, but rather complementary methodologies.

Hypothesis 4: This hypothesis is partially confirmed since both the GG and the LGG had better knowledge acquisition on post-test 1 than the LG and the CG (Fig. 3). This indicates that the Nutrikids game can be used either in classes with only the game or in a combination of traditional classes with the game. When used with lecture classes, the game works as a way of emphasizing subjects that have already been covered; when employed alone, the students learn from interacting with the levels of the game.

Hypothesis 5: This hypothesis is also confirmed. Concerning post-test 2, the GG was the only group that continued to score significantly higher than on the pre-test. When analyzing the scores of post-test 2, only the GG still had significantly higher scores, concerning their pre-test and to the post-test 2 scores of the other groups. This suggests that the use of the game motivated the students by actively providing learning and that the contents were thus acquired more effectively, leading to greater knowledge retention.

These results provide compelling evidence for knowledge retention after one month without further intervention in students who use digital education with serious games, suggesting that this approach was effective for the retention of nutritional knowledge.

\section{Conclusion}

The present study evaluated the effect of game-based learning through the Nutrikids game regarding the development of nutritional knowledge in Brazilian students. The children were divided into one $\mathrm{CG}$ and the following three groups with different interventions: the LG, whose intervention consisted of expository lectures only; the GG, whose intervention consisted of the Nutrikids game; and the LGG, which received half of the intervention with lecture classes and the other half with the Nutrikids game. The results showed that the students had little nutritional knowledge before the study and that, one month after the intervention, the GG and the LGG 
obtained greater learning improvement when compared to the LG and CG groups. It was also found that there was no difference between sex and that, after one month without further intervention, the GG was the one with the greatest knowledge retention. In summary, the results found in the present study indicate that nutritional knowledge in students with the Nutrikids game was more efficient, both for enhancing knowledge immediately after the intervention and about retention one month after the end of the intervention. It is planned, as a future study, to apply the game during a longer period with a larger sample and to assess whether sociodemographic characteristics influence the acquisition of knowledge from game-based learning interventions.

\section{References}

ABARCA-GÓMEZ, Leandra et al. Worldwide trends in body-mass index, underweight, overweight, and obesity from 1975 to 2016: a pooled analysis of 2416 population-based measurement studies in 128. 9 million children, adolescents, and adults. The Lancet, v. 390, n. 10113, p. 2627-2642, 2017.

ABDUL JABBAR, Azita Iliya; FELICIA, Patrick. Gameplay engagement and learning in game-based learning: A systematic review. Review of educational research, v. 85, n. 4, p. 740-779, 2015.

BARANOWSKI, Tom et al. Nutrition education and dietary behavior change games: A scoping review. Games for health journal, v. 8, n. 3, p. 153-176, 2019.

BATTISTELLA, Paulo Eduardo; VON WANGENHEIM, Christiane Gresse. Engaged: Um processo de desenvolvimento de jogos para ensinar computaçao. In: Brazilian Symposium on Computers in Education (Simpósio Brasileiro de Informática na Educação-SBIE). 2016. p. 380.

BORGONOVI, Francesca. Video gaming and gender differences in digital and printed reading performance among 15-year-olds students in 26 countries. Journal of Adolescence, v. 48, p. 45-61, 2016

Brazil. Ministério da Saúde. (2008). Guia alimentar para a população brasileira: promovendo a alimentação saudável. Ministério da Saúde.

Brazil. Ministério da Saúde. (2014). Guia alimentar para a população brasileira. Ministério da Saúde.

Brazil, Ministério da Saúde. (2018). Vigilância de fatores de risco e proteção para doenças crônicas por inquérito telefônico: estimativas sobre frequência e distribuição sociodemográfica de fatores de risco e proteção para doenças crônicas nas capitais dos 26 estados brasileiros e no Distrito Federal em 2017. Ministério da Saúde.

BYUN, JaeHwan; JOUNG, Eunmi. Digital game-based learning for K-12 mathematics education: A meta-analysis. School Science and Mathematics, v. 118, n. 3-4, p. 113-126, 2018.

CONNOLLY, Thomas M. et al. A systematic literature review of empirical evidence on computer games and serious games. Computers \& education, v. 59, n. 2 , p. 661-686, 2012.

HAMER, Mark; BATTY, G. David. Association of body mass index and waist-to-hip ratio with brain structure: UK Biobank study. Neurology, v. 92, n. 6, p. e594-e600, 2019.

HOLZMANN, Sophie Laura et al. Digital gaming for nutritional education: a survey on preferences, motives, and needs of children and adolescents. JMIR formative research, v. 3, n. 1, p. e10284, 2019. 
HUIZENGA, J. C. et al. Teacher perceptions of the value of game-based learning in secondary education. Computers \& Education, v. 110, p. 105-115, 2017.

LOBSTEIN, T.; JACKSON-LEACH, R. J. P. O. Planning for the worst: estimates of obesity and comorbidities in school-age children in 2025. Pediatric Obesity, v. 11, n. 5, p. 321-325, 2016.

MACHADO, Cleiton Carvalho et al. Master Prato: Jogo em Realidade Aumentada para Auxílio no Desenvolvimento de Hábitos Alimentares Saudáveis em Crianças. RENOTE, v. 18, n. 1, 2020.

NISHTAR, Sania; GLUCKMAN, Peter; ARMSTRONG, Timothy. Ending childhood obesity: a time for action. The Lancet, v. 387, n. 10021, p. 825-827, 2016.

ONIS, Mercedes de. Preventing childhood overweight and obesity. Jornal de pediatria, v. 91, n. 2, p. 105-107, 2015.

PARMENTER, Kathryn; WARDLE, Jane. Development of a general nutrition knowledge questionnaire for adults. European journal of clinical nutrition, v. 53, n. 4, p. 298-308, 1999.

PRENSKY, Marc. Aprendizagem baseada em jogos digitais. São Paulo: SENAC, v. 575, 2012.

REIS, Caio Eduardo G.; VASCONCELOS, Ivana Aragão L.; BARROS, Juliana Farias de N. Políticas públicas de nutrição para o controle da obesidade infantil. Revista paulista de pediatria, v. 29, n. 4, p. 625-633, 2011.

SAVI, Rafael; ULBRICHT, Vania Ribas. Jogos digitais educacionais: benefícios e desafios. RENOTE-Revista Novas Tecnologias na Educação, v. 6, n. 1, 2008.

SERA, Leah; WHEELER, Erin. Game on: The gamification of the pharmacy classroom. Currents in Pharmacy Teaching and Learning, v. 9, n. 1, p. 155-159, 2017.

Souza, J. (2009). Conhecimentos nutricionais: reprodução e validação do questionário (Doctoral dissertation, Universidade do Porto. Faculdade de Medicina. Instituto de Ciências Biomédicas Abel Salazar).

WOUTERS, Pieter et al. A meta-analysis of the cognitive and motivational effects of serious games. Journal of educational psychology, v. 105, n. 2, p. 249, 2013. 